Joan D. Krizack

\title{
Preserving the History of Diversity: One University's Efforts to Make Boston's History More Inclusive
}

IN 1994, ON THE EVE OF ITS CENTENNIAL, Northeastern University, located in the Roxbury neighborhood of Boston, hired its first professional to head the University Archives and Special Collections Department. What I inherited was an archivist's nightmare. Every document had been cataloged like a book, with a unique catalog number. None of the manuscript collections had been processed. There was no collecting policy. The papers of a Massachusetts governor existed alongside those of an individual who was instrumental in developing insurance education; the records of an early swing-era orchestra resided next to those of Freedom House, a community activist organization: these unrelated collections comprised Northeastern's Special Collections in the early 1990s. The time was clearly right to establish department standards and develop a collecting policy that was suited to the mission of Northeastern, yet would not duplicate the collecting efforts of other local repositories.

Northeastern University was founded in 1898, an outgrowth of the Evening Institute for Young Men of the Boston Young Men's Christian Association. According to its first president, Frank Palmer Speare, Northeastern "started with an eraser and two sticks of chalk." Certainly, the university's beginnings were humble. In 1909, Northeastern initiated the second program of cooperative education in the United States, which was essentially a modernization of the apprentice system, adapted to the needs of industry for training technical workers in the early 20th century. A major benefit of cooperative education through the mid-20th century was that it provided a way for young men of limited means to pay for the cost of their education. Northeastern's emphasis on cooperative education continues and remains one of its distinguishing characteristics. By the mid-1990s, the University described itself as a "national research university that is student-centered, practice-oriented, and urban." Its stated mission was "to provide individuals [described elsewhere as "a pluralistic student population"] with the opportunity for upward mobility through excellence in education." 


\section{Developing a Collection Focus}

A range of significant factors were carefully considered before deciding that social justice organizations and activists would be our collecting focus: Northeastern's origins and its current mission as a diverse, urban, research university; the lack of documentation within established manuscript repositories of certain of Boston's communities; Northeastern's commitment to the local community; the fact that the Freedom House collection-for which the National Historical Publications and Records Commission had awarded us a processing grant in 1996 - could attract other collections relating to social justice; and, quite frankly, my own enduring interest in social justice. We further refined the collecting policy to relate specifically to Boston's African American, Chinese, Latino, and gay and lesbian communities, since at the time these were among Boston's largest minority communities: they each had grassroots social justice organizations that date back 30-50 years, and three of the communities were already connected to the Northeastern University Archives by virtue of having a significant collection housed there.

Reflecting on the past ten years, all indications are that the collecting focus was well chosen. Caring for historical records of local individuals and organizations and providing them with records management guidance has made a noteworthy contribution to what the University gives to its community. ${ }^{1}$ Because the University does not pay taxes to the City of Boston, it is important that Northeastern be able to demonstrate that it is a good neighbor. The collecting policy has also been good for the University Library, the parent entity of the Archives and Special Collections Department, because it has brought recognition of the Library's ability to contribute to the positive image of the University in a way that otherwise might not have been possible. An additional testament to the collecting policy is that it has survived a change in university presidents. In fact, our current president enthusiastically supports our efforts to document social justice in Boston and has actively participated in efforts to attract new collections to Northeastern. Ten years later, in response to requests from other underrepresented groups, we have broadened our collecting focus to include documenting social justice activists and organizations without reference to specific underrepresented communities.

\section{Collecting}

In 1998, our collecting efforts were catalyzed by a second grant from the National Historical Publications and Records Commission, which funded the processing of

1. While we are not able to provide traditional records management services to these organizations, we do develop documentation plans for them that detail, for example, what functions are important to document, what record series are important to preserve, and what records series are not archival. To view the documentation plan for Inquilinos Boricuas en Acción (IBA), go to: http:/ / hdl.handle.net/2047/ d10002467. 
three collections_-La Alianza Hispana, National Center for Afro-American Artists, and AIDS Action Committee of Massachusetts ${ }^{2}$ - and enabled us to hire a professional archivist to work with members of the African American, Chinese, Latino, and gay and lesbian communities to identify organizations and individuals on whom our collecting effort should focus. The goal of the processing component of the two-year grant was to help demonstrate to potential donors our commitment not only to preserving the material but also to making it more accessible; the goal of the collecting part of the project was to develop a framework for ongoing collecting of historical material relating to the four underrepresented communities. At the same time that project staff was processing the three collections, other staff members worked with separate advisory boards for each group, composed of community activists, academics, and information professionals, to create a framework, identify, and prioritize the social justice organizations that were important for us to document. ${ }^{3}$

Working with the community groups was as fascinating as it was difficult. We found it to be a challenge to convene a meeting and get a critical number of members to attend. Yet, we could not accomplish the project's goals without their help. We discovered that it was advantageous to appoint a lead advisor for each group, who had connections both to the community and to Northeastern, and was, therefore, more interested in the project. If we were to do a similar project in the future, we would write into the grant proposal compensation for our advisors, to provide additional motivation to participate more fully.

Once our priorities had been set by the advisory groups, we began soliciting collections, which, it seems, is a lot like soliciting money: you make your pitch, but you never know when — or if ever — it is going to come to fruition. We researched each organization that had been identified as a priority, trying to determine if it had any connections to Northeastern, such as joint programs, or board members who worked at the University, or if members of our advisory board had connections to the organization's board of directors. When we did find a connection, we capitalized on it to get the attention of the organization's director; if we did not find a connection, our approach was to send a solicitation letter along with a brochure that explained the collecting program, why it is important, and how to participate in it. ${ }^{4}$ About ten days later, I called the organization's executive director and set up a meeting. The first meeting usually occurred at the organization. If there was interest in

2. Our intention had been to process one collection from each of the four identified communities; however, at the time the grant proposal was submitted, we did not have a collection relating to the Chinese community, so we could not include processing a Chinese collection in the proposal.

3. For a detailed description of the grant project, see: Nancy Richard and Joan D. Krizack, "Preserving the History of Boston's Diversity," Provenance XVII (1999): 23-51.

4. We developed four different brochures, one for each of the communities; the brochures for the Latino and Chinese communities are bilingual. They may be viewed at: www.lib.neu.edu/archives/boston/index.html. 
the project, then I set up a meeting with the organization's board or other appropriate individuals to tour the Archives. This was the basic plan we began with and continue to use, but we are flexible in our approach as necessary.

At first, I could not understand why some organizations were not immediately receptive to Northeastern's offer to preserve their historical records. It seemed to me to be self-explanatory: Northeastern would do all the work, and the organization's historically significant records would be preserved and made available for future generations. But I gradually began to understand that some were suspicious of the University and would prefer to place their records with an institution that was run by and dedicated to their particular group. Although such an approach is understandable and may be desirable, it is expensive and, therefore, often impractical.

Perhaps obviously, the first collections from each community were the most difficult to acquire. Significant groundwork was completed during the two-year grant period, although collecting has decelerated, understandably, since the grant ended, along with the position dedicated to collection development. Ten years after our initiative began, we have a total of 81 collections (approximately 1,200 linear feet of material) relating to our collecting focus, 52 of which have been processed. In addition, we are in negotiation with about 25 organizations and individuals for their historical materials. Although the advisory groups disbanded at the conclusion of the grant period, it is gratifying to note that several individuals who used to work for the University contact me with some regularity about collecting opportunities that come to their attention. Even more significant is the fact that the University's new president values our collecting effort, and he has asked a number of individuals working for the University's Public Relations and Community Relations offices to collaborate with the Archives in identifying and securing appropriate collections. Because we religiously publicize collections when they are acquired and again when they have been processed, and because we spoke and wrote about our grant project in the appropriate venues, the archival community, the Northeastern community, and the local communities are all aware of the Archives' collecting project. This has resulted in a fortunate turn of events, as we now get calls directly from organizations asking us to preserve their historical records.

\section{Use of the Collections}

The materials we have acquired, even those from ongoing organizations, are in effect manuscript collections rather than archives. Surprisingly few requests for these materials have been made by the organizations that created the collections, and most have been in preparation for anniversary celebrations. There have been a range of other users from the community: staff of the Boston Museum Project looking for photographs for a fundraising brochure; the editor of the local African 
American newspaper seeking photographs for an article on Lower Roxbury; a public television producer researching a documentary on Villa Victoria; a high school student writing a paper on the Metropolitan Council for Educational Opportunity; individuals searching for images of Martin Luther King Jr. for promotional material for a civil rights symposium; a consultant researching the Elma Lewis School of Fine Arts for a documentary; and a volunteer from the Boston Women's Heritage Trail researching the South End House. We have also had group visits from local history organizations and school classes.

In the scholarly community, our collections are well used by students and faculty connected to Northeastern and by outside researchers from across the country. Northeastern undergraduates have written papers on the Urban Schools Collaborative; Boston's early response to the AIDS / HIV crisis; organizations and services for gay and lesbian youth in Boston; the first bilingual Latino day care center in Massachusetts; feminist organizations in Boston from 1970-1980; and prisoners' rights projects. Numerous undergraduate and graduate students have written senior theses and dissertations on topics including the busing crisis in Boston; urban renewal; the African American struggle for equal housing opportunity; and Elma Lewis. University of Chicago sociologist Mario Luis Small used the records of Inquilinos Boricuas en Acción for his book, Villa Victoria: the Transformation of Social Capital in a Boston Barrio, ${ }^{5}$ and Northeastern University sociology professor Winifred Breines used some of our collections in writing The Trouble Between Us: An Uneasy History of White and Black Women in the Feminist Movement. ${ }^{6}$

\section{Reflections}

In reflecting on our ongoing collecting project, there are several points that seem worth mentioning.

- First, there is plenty of diversity within each community. We realized early on that we were cavalierly referring to African American, Chinese, Latino, and gay and lesbian communities as though each one was a homogeneous entity. This is, obviously, not the case. The more we began to learn about each group, the more we began to understand that each of them comprises, for example, multiple points of view regarding politics and religion, and multiple customs and traditions. It is critical to keep this in mind as we continue the documentation project.

5. Mario Luis Small, Villa Victoria: the Transformation of Social Capital in a Boston Barrio (Chicago: University of Chicago Press, 2004).

6. Winifred Breines, The Trouble Between Us: An Uneasy History of White and Black Women in the Feminist Movement (Oxford: Oxford University Press, 2006). 
- The importance of a well-selected advisory group should not be underestimated. At least some of the advisory group members should be members of the community, and they should represent a broad range of viewpoints. Advisors are important in identifying and setting priorities for determining which organizations and individuals should be documented, initiating contact with potential donors, helping staff understand the culture and complexity of the community, and publicizing the collecting effort. If funding is available to pay advisory group members, better results will be obtained.

- We were most successful with potential donors when we discussed preserving their historical records as a collaborative effort. We wanted to convey to them that donating their records to Northeastern was a mutually beneficial situation: their historical records would be organized, preserved in a secure, temperature- and humidity-controlled environment, and made available for research without any cost to them; the space that the records had occupied while at the organization would be freed for another use; and Northeastern would increase its research resources at the same time it provided a community service. Before we adopted this approach, some donors feared that the University was trying to take something away from the community.

- It took project staff some time to admit that while we at Northeastern are totally committed to preserving and making historical records accessible, this is probably not a high priority of the organizations and individuals whom we approached as potential donors. In fact, they may not ever have considered the importance of documenting their efforts, since they are primarily concerned with running their organizations-including managing programs, preparing for annual meetings, and planning fundraising events - which usually demands so much staff time that little, if any, time remains for thinking about or dealing with historical records. So, in pitching our project to donors, we emphasize that after the deed of gift is signed, the Archives staff does all the documentation work.

- A corollary to the previous point is that patience and persistence are imperative. Sometimes the process from initial contact with a donor to the arrival of the collection in the Archives happens within a few weeks; other times it may take years. And there is no way to predict how long it will take. For example, I first contacted one organization in November 2002 and received a positive response, but it then took more than a year 
to set up a meeting for me to make a presentation to the board. That meeting occurred two years ago, and while I have been assured multiple times that they are still interested in working with Northeastern to preserve the organization's records, we have not made any more progress to that end in spite of my periodic telephone calls.

- Negotiating gift agreements can proceed apace, or it can be fraught with demands, both reasonable and unreasonable. One organization insisted that we provide it with copies of every item in its collection. This was a deal breaker. I am, however, planning to approach the organization again, once the current CEO has been replaced. The question of financial gain is another issue that surfaced. One organization feared that Northeastern University would make money from their collection, so we compromised, agreeing to share equally in any profit made from reproducing photographs for publication.

- On occasion, collections will be offered without any prior solicitation. This began to happen after we had acquired the papers from several organizations and became known for collecting records of Boston's underrepresented communities. After ensuring that the collection fits in with the institution's collecting focus, we enjoy this serendipity, and are not overly concerned if the processing of the collection cannot immediately be a high immediate priority.

- To gain the confidence of the communities you are documenting, it is important to demonstrate a long-term commitment to preserving and making the collections accessible. If we process the collections as rapidly as possible, publicize them when they become available for research, and commit to taking future accretions of organizations that are still in operation, we find that it is easier to attract more material.

- Be prepared for unusual requests. One important organization wanted Northeastern to endow a scholarship for a member of the community it served in exchange for donating its records to the Archives. Another organization asked that the University hold an annual symposium relating to the topic of its records. While these requests were not unreasonable, they were out of the scope of what the University Archivist or the Dean of Libraries could grant.

- Multiple invitations will be forthcoming. Regularly, I receive invitations to annual meetings, and fundraising events, and solicitation letters from 
the organizations for whose records we are caring. One organization even requested that I play a prominent role in its fundraising efforts. (If only I were able to contribute to all of the worthwhile causes these organizations represent!) But attending at least some of these events will increase one's understanding of the community and help to gain its trust.

\section{Conclusion}

Collecting records documenting social justice in Boston's African American, Chinese, Latino, and the gay, lesbian, bisexual, and transgender communities continues to be exciting and rewarding. In fact, each time a collection is acquired, I feel as if I have won the lottery. The records we are collecting contain rich documentation of significant themes relating to school desegregation, public policy formation, public health issues, community relations, affordable housing, urban planning, social service delivery, cultural programming, violence prevention, and minority rights during the last decades of the 20th century and beyond. The records often provide perspectives different from the information and opinions presented by conventional media and in the traditional historical documentation. Material that is created by members of underrepresented communities offers clues for understanding events that may have been ignored, misunderstood, or misrepresented in traditional sources. They document community issues and accomplishments; they describe the motivation for and the process of working for change; they provide insights into the diversity of individuals and the range of opinions within each community; and they help to instill pride in the community's successes and evaluate its setbacks. If this documentation is not preserved, the historical record will be devoid of the vital viewpoints of the community members themselves. By providing access to this material, we in turn help ensure that history more accurately reflects the inclusiveness and diversity of our contemporary society.

\section{David M. Lesser Fine Antiquarian Books LLC \\ One Bradley Road \#302, Woodbridge, CT 06525 \\ Tel: (203) 389-8111 Fax: (203) 389-9113 \\ Email: dmlesser@lesserbooks.com \\ Website: http://www.lesserbooks.com}

